\title{
An Analysis of Presupposition Triggers in Hilary Clinton's First Campaign Speech
}

\author{
Ruiqing Liang ${ }^{1} \&$ Yabin Liu ${ }^{1}$ \\ ${ }^{1}$ School of Foreign Studies, Jinan University, Guangzhou, China \\ Correspondence: Yabin Liu, School of Foreign Studies, Jinan University, Guangzhou, China. E-mail: \\ 1181605869@qq.com
}

Received: July 19, 2016 Accepted: August 9, 2016 Online Published: September 23, 2016

doi:10.5539/ijel.v6n5p68 URL: http://dx.doi.org/10.5539/ijel.v6n5p68

This paper is supported by "the Fundamental Research Funds for the Central Universities" (grant no.: 15JNYH007) and "the National Social Science Foundation of China" (grant no.:12BYY119).

\begin{abstract}
Presupposition triggers play a vital role in verbal communication. Based on Hilary Clinton's first campaign speech, this paper intends to analyze the presupposition triggers at both lexical and syntactic levels, for the purpose of figuring out how Hilary succeeds in achieving her political intentions through the use of presupposition triggers, hoping to contribute to the composition and understanding of political speeches.
\end{abstract}

Keywords: presupposition triggers, presupposition, Hilary Clinton, political speech

\section{Introduction}

Presupposition, first put forward by German philosopher Gottlob Frege in 1892, was originally studied in philosophy of language and later introduced to the field of linguistics. As the study of presupposition continues, it has been found that presuppositions are typically generated by the use of lexical items or linguistic constructions. These lexical items and linguistic constructions are called presupposition triggers (Levinson, 1983; Huang, 2007). Presupposition has long been used as a property of language to mold the audience's ideology. Using presupposition triggers, the author or speaker may well impinge on the reader's or listener's interpretation of facts and events, establishing either a favorable or unfavorable bias throughout the text (Zare, 2012). Presidential campaign speech, as a specific type of political discourse, is to help the speaker gain voters' support by virtue of various linguistic devices and emotional incitement. An analysis of the presupposition triggers used in presidential campaign speeches and their contribution to the realization of the speaker's political goals can help to deepen our understanding of political speeches.

This paper intends to study the successful campaign speech delivered by American presidential candidate Hilary Clinton in Roosevelt Island of New York City in 2015, in which she insisted that America should enter a new era of common prosperity and appealed to the working class that she would fight for everyone in the country. Through a qualitative study of the presupposition triggers used in the speech, this paper hopes to figure out how Hilary succeeds in achieving her political intentions through the use of presupposition triggers.

\section{Theoretical Framework}

\subsection{Presupposition}

Presupposition, which refers to something that is presupposed, serves as the starting point from which an assertion is made or proposition is expressed. Levinson (2001) defined presupposition as the common ground embedded in an utterance which is taken for granted by all the participants in a speech event, including the speaker/writer and the listener/reader. Huang (2007) described it as a piece of information or a proposition whose truth is taken for granted in the utterance of a sentence. According to Richardson (2007), presupposition refers to the information triggered by certain linguistic constructions which is irrefutably credited as absolute truth by participants in an utterance in a specific context. Huang (2011) pinned down two main properties of presupposition, namely constancy under negation and defeasibility. In the former case, a presupposition generated by the use of a lexical item or a syntactic structure remains the same even when that statement is 
negated. In the latter case, presuppositions tend to be cancelled if they are inconsistent with background assumption, conversational implicatures and certain discourse context. Dryer (1996) also included "being back-grounded and taken for granted" as the main properties of presupposition. While presupposition has in general been regarded as a heterogeneous collection of quite distinct and different phenomena (Levinson, 1983), with the deepening of presupposition study, more words and constructions which give rise to presupposition, known as presupposition triggers, have been found.

\subsection{Presupposition Triggers}

Many linguists have dedicated themselves to collecting and analyzing presupposition triggers. Karttunen (1971) once listed thirty-one kinds of presupposition triggers. On the basis of Karthunen's research, Levinson (1983) listed thirteen types of presupposition triggers, including definite description, factive verbs, imperative verbs, change of state verbs, iterative, verbs of judging, temporal clauses, cleft sentence, implicit clefts with stressed constituents, comparison and contrasts, non-restrictive relative clauses, counter-factual conditionals, questions. Yule (2010) categorized presupposition triggers into six groups, including existential, factive, lexical, structural, non-factive and counter-factual triggers. Chinese scholar He Ziran (2003) reclassified Levinson's thirteen kinds of presupposition triggers into three general groups. They are verbs including implicative verbs, factive verbs, change-of-state verbs, and verbs of judging; iteratives and adjuncts such as "again", "another", "back", "either", "even", "s", "too", and "the"; and phrases and clauses including temporal clauses, comparisons and contrasts, non-restrictive relative clauses, cleft sentences, and questions as well.

Inspired by He's classification of presupposition triggers into verbs, iteratives and clauses, combining both Levinson's and Yule's classifications, this paper attempts to reclassify the presupposition triggers into two levels: the lexical level and the syntactic level based on the reclassifications of presupposition triggers by $\mathrm{Li}(2010)$ and $\mathrm{Du}$ (2012). To make it clearer, the classification of presupposition triggers of the present study is shown in Table 1.

Table 1. Classification of presupposition triggers

\begin{tabular}{|c|c|c|c|}
\hline Presupposition Triggers & Classification & & Examples \\
\hline \multirow{10}{*}{ Lexical Level } & \multirow{5}{*}{ Verbs } & Factive Verbs & know, realize, regret, be glad that.. \\
\hline & & Implicative Verbs & manage, forget, avoid... \\
\hline & & Iterative Verbs & restore, return, come back... \\
\hline & & Change-of-state Verbs & stop, begin, continue... \\
\hline & & Verbs of Judging & praise, accuse, criticize... \\
\hline & \multirow{3}{*}{$\begin{array}{l}\text { Restrictive } \\
\text { Expressions }\end{array}$} & (In)definite articles & a, an, the \\
\hline & & Pronouns & his, her, our, their... \\
\hline & & Other expressions & another, only... \\
\hline & \multicolumn{2}{|c|}{ Iterative Particles } & again, too, either. \\
\hline & \multicolumn{2}{|c|}{ Other particles } & even, still, just... \\
\hline \multirow{6}{*}{ Syntactic Level } & \multicolumn{2}{|c|}{ Temporal clauses } & after, during, whenever, when, as.. \\
\hline & \multicolumn{2}{|c|}{ Comparison and contrasts } & $\begin{array}{l}\text { more than, as much as, comparative } \\
\text { constructions... }\end{array}$ \\
\hline & \multicolumn{2}{|c|}{ counter-factual conditionals } & conditions contrary to facts \\
\hline & \multicolumn{2}{|c|}{ non-restrictive relative clauses } & who, which, when, where... \\
\hline & \multicolumn{2}{|c|}{ Cleft sentences } & It is/wasn't...that/who... \\
\hline & \multicolumn{2}{|l|}{ Questions } & $\begin{array}{l}\text { Yes/no questions, rhetorical questions, } \\
\text { wh-questions }\end{array}$ \\
\hline
\end{tabular}

\section{Presupposition Triggers in Hilary's Campaign Speech}

There are many presupposition triggers employed in Hilary's campaign speech. This study will provide a detailed analysis of them at both lexical and syntactic levels. The symbol " $>>$ " is used to stand for "presupposes" and both lexical and syntactic presupposition triggers are in italics in this paper.

\subsection{Lexical Presupposition Triggers}

As shown in the table, presupposition triggers at the lexical level include verbs, restrictive expressions, iterative particles and other particles. An analysis of lexical triggers in Hilary's speech will be conducted in the following respects. 


\subsubsection{Iteratives}

This study intends to combine iterative verbs with iterative particles in the category of iteratives, which refer to the words that indicate repetition including verbs and adverbs such as repeat, restore, reestablish, again, too, more, and another. They presuppose previous existence of certain action or state. Hilary's speech features frequent use of iteratives. Here are some examples.

(1) We will restore America to the cutting edge of innovation, science, and research by increasing both public and private investments.

>>America had once stood in the cutting edge of innovation, science and research.

The iterative verb "restore" chosen here by Hilary presupposes that America once played a leading role in innovation and scientific research around the world. But America has lost the glory for some reasons. Hilary shows her willingness to lead the country back to the glorious days by making some positive changes in public and private investments. By this presupposition, Hilary guides the audience to reflect on the current situation and help them build up the hope and confidence in American scientific research in the future.

(2) I will rewrite the tax code so it rewards hard work and investments here at home, not quick trades or stashing profits overseas.

>> There once existed a tax code.

Hilary uses the iterative verb "rewrite" here to presuppose that the current tax code is imperfect since its beneficiaries turn out to be quick trades or stashing profit overseas. Through this presupposition, Hilary shows her dissatisfaction with the present tax code as well as her sympathy for the hard work and investments at home. Hence Hilary successfully gains favor from the audience and enters into a closer relationship with them.

(3) To make the middle class mean something again, with rising incomes and broader horizons.

>> The middle class once meant something.

The iterative particle "again" here triggers the presupposition that the middle class used to mean a lot to the country. However, in the current situation, the middle class people don't gain enough growth or fairness that they deserve. Here Hilary means to demonstrate her concern for the middle class and her determination to make a change, thus gaining positive response from the middle class.

\subsubsection{Change-of-state Verbs}

Change-of-state verbs are the verbs which involve the shift of a kind of behavior or state. They presuppose that something has been in certain place or state before. Verbs in this category include stop, begin, continue, finish, change, cease, come, go, etc. As is known to all, America has just recovered from a global financial crisis. Under such a circumstance, Hilary is eager to show her resolution to change America's status quo. Therefore, change of state verbs are widely used in Hilary's campaign speech.

(4) The story of America is a story of hard-fought, hard-won progress. And it continues today.

>> The progress of America used to be unusually hard.

Hilary talks about the hardships their ancestors have endured and the perseverance they have shown on their way to progress and happiness. She uses the change-of-state verb "continue" here to trigger the presupposition that American people should carry on with the tough journey for the final victory. Thus, the presupposition enables the public to be vigilant and also serves as an encouragement for the public to overcome the unknown difficulties ahead of them.

(5) We have to stop the endless flow of secret, unaccountable money that is distorting our elections, corrupting our political process, and drowning out the voices of our people.

>> There exists the endless flow of secret, unaccountable money that is corrupting our political election.

The change-of-state verb "stop" used in this example presupposes that American elections and political process are being distorted by endless flow of secret and money. Through the presupposition, Hilary hopes to reveal the dark side in the current political process, which drowns out the real voice of the public. She is unsatisfied with the current political situation and calls on the public to do something to stop it.

\subsubsection{Restrictive Expressions}

Restrictive words refer to the words that are used to modify a noun phrase, including not only some definite and indefinite articles like "a" and "the", but also some adjectival possessive pronouns like his, their etc. This kind of presupposition also takes up a large proportion in Hilary's speech. 
(6) Now, building an economy for tomorrow also requires investing in our most important asset, our people, beginning with our youngest.

>>There are our most important asset, our people and our youngest.

The adjectival possessive pronoun "our" triggers an existential pragmatic presupposition that by putting into our most important asset, our people and even our youngest, we can build an economy for tomorrow. Hilary intends to emphasize every American's identity as a master of the country. Hence, the presupposition successfully calls on the public to be united as one and concentrate their effort on achieving a prosperous economy for the future. Besides, it serves as an artful device to draw the public closer to the speaker.

\subsubsection{Other Particles}

Besides the above categories, there are also many particles in the said speech. The study will mainly focus on the use of "even" and "not only" in the speech.

(7) An America where a father can tell his daughter: yes, you can be anything you want to be. Even President of the United States.

$>>$ Few American women have ever thought about being the President of the United States.

The particle "even" here indicates the progressive relationship between the two sentences. It triggers the presupposition that few American women have the courage to consider being the President. As we all know, there has never been any female President in the American history. Hilary quotes her father's words here to indirectly express her ambition and resolution, especially as a woman, thus leaving a deep impression on the public.

(8) The first is to make the economy work for everyday Americans, not just those at the top.

$>>$ The first is to make the economy work for everyday Americans, not just those at the top, but also the middle class and the poor.

The particle "not only" used by Hilary here is to presuppose that economy should not only work for the top but also for those middle class and underclass. Hilary didn't make explicit the middle class and the poor, but this is exactly what she wanted to stress out. Through the presupposition, her words can make an echo in the hearts of the public, especially those in middle class and underclass of the society.

To sum up, through the use of lexical presupposition triggers, presupposition can be projected more easily. What's more, the employment of lexical presupposition triggers can simplify the words so as to avoid lengthiness and prolixity, to stress out the important information, to change the relationship between the speaker and the audience and, more importantly, to help the audience understand the presupposed information in the political speeches.

\subsection{Syntactic Presupposition Triggers}

Besides lexical presupposition triggers, there are also many presupposition triggers at the syntactic level in the speech, which can be studied in the following two respects.

\subsubsection{Comparisons and Contrasts}

Levinson (2001) concludes that comparisons and contrasts may be marked by stress, some particles like too, back, and comparative constructions. The original states being compared and contrasted with are the presuppositions. In Hilary's speech, a lot of such presupposition triggers have been exploited to the full. For instance,

(9) While many of you are working multiple jobs to make ends meet, you see the top 25 hedge fund managers making more than all of America's kindergarten teachers combined.

>>All of America's kindergarten teachers make money.

The comparative structure used here presupposes that all American kindergarten teachers earn a certain number of salary, the sum of which, however, is less than what twenty-five hedge fund managers earn, which reveals an excessive disparity in income between those at the top and those at the bottom. Hilary employs this presupposition here to express her deep concern for the welfare of ordinary Americans, in the hope of resonating with the general public and gaining their support.

(10) The middle class needs more growth and more fairness.

$>>$ There exists growth and fairness in the middle class. 
The two comparison markers "more" are adopted here to presuppose that middle class people are living in a circumstance where they can gain some growth as well as fairness. However, according to Hilary, the growth and fairness they have got is not enough. More efforts and investments need be devoted to improving the situation of middle class. With the presupposition triggered, Hilary's social concern for people's vital interests is well presented.

\subsubsection{Questions}

As shown in Table 1, there are three main types of questions, namely "yes or no" questions, rhetorical questions, and wh-questions. Levinson (1983) pointed out that questions generally share the presupposition of their assertive counterparts and interrogative forms to introduce further presuppositions. He further stated that "yes or no" questions usually have meaningless presupposition (ibid). The present study will mainly focus on wh-questions, together with rhetorical questions, which are generally to make a point rather than to elicit an answer (Burton, 2007). In the following are some examples.

(11) "When does my hard work pay off? When does my family get ahead?"

>>My hard work pays off and my family will get ahead at a certain time.

The two wh-questions introduced by "when" here trigger the presupposition that every American's hard work should pay off and every family should go ahead. However, the fact is that neither of them has been realized. By emphasizing the status quo of the American working class, Hilary puts herself in the shoes of the public so as to arouse their resonance.

(12) Ask many of these candidates about climate change, one of the defining threats of our time, and they'll say: "I'm not a scientist." Well, then, why don't they start listening to those who are?

> They never start listening to those who are scientist.

The rhetorical question employed here is to presuppose that many presidential candidates just go their own way without listening to others' opinions. With the presupposition, Hilary wants to condemn the ignorance and irresponsibility of certain candidates and intends to communicate her political message of respecting and accepting the public opinions to the audience. As a result, the syntactic triggers would hopefully prompt the American people to trust and support her rather than other candidates.

In brief, just like lexical presupposition triggers, syntactic ones also play an essential role in making apolitical speech successful. Usually, the comparisons and contrasts are used to emphasize some important information and leave a deep impression on the public. Questions also frequently appear in political speeches to evoke the audience to think over the questions and arouse their resonance. In this way, the speaker can actively and effectively interact with the audience.

\section{Conclusion}

Based on an analysis of presupposition triggers found in Hilary Clinton's first campaign speech, it can be argued that the abundant use of presupposition triggers helps to better communicate her political messages and consequently grip her audience. Presupposition triggers, including lexical and syntactic ones, play an indispensable role in strengthening important information, making language more economical and vivid, motivating the interaction with the audience and drawing a closer relationship between the speaker and the audience, so as to help the speaker achieve his or her real political goals. The present study of presupposition triggers in political speeches hopes to contribute to the composition of as well as a better understanding of the political speeches.

\section{References}

Burton, G. O. (2007). Rhetorical questions. Brigham Young University.

Dryer, M. S. (1996). Focus, Pragmatic presupposition, and activated propositions. Journal of Pragmatics. http://dx.doi.org/10.1016/0378-2166(95)00059-3

Du, Y. H. (2012). An Analysis of the Use of Pragmatic Presuppositions in Obama's Inaugural Address. Nanjing: Nanjing Normal University.

Frege, G. (1892). On Sense and Reference. In P. Geach \& M. Black (Eds.), Translation from the Philosophical Writings of Gottlob Frege. Oxford: Blackwell. http://dx.doi.org/10.2307/2181485

He, Z. R. (2003). Notes on Pragmatics. Nanjing: Nanjing Normal University Press.

Huang, Y. (2007). Pragmatics. Oxford: Oxford University Press. 
Huang, Y. (2011). Types of inference: entailment, presupposition, and implicature. In W. Bublitz \& N. R. Norrick (Eds.), Foundation of Pragmatics. Berlin: De Gruyter Mouton. http://dx.doi.org/10.1515/9783110214260.397

Karttunen, L. (1971). Implicative verbs. Language. http://dx.doi.org/10.2307/412084

Levinson, S. C. (1983). Pragmatics. Cambridge: Cambridge University Press.

Levinson, S. C. (2001). Pragmatics. Beijing: Foreign Language Teaching and Research Press.

Li, X. X. (2010). A Presuppositional Study of American Political Discourse-Based on the Speeches by American President Obama. Shandong: Shandong Normal University.

Richardson, J. E. (2007). Analyzing newspapers: An approach from critical discourse analysis. NY: Palgrave, Macmillan.

Yule, G. (2010). Pragmatics. Oxford: Oxford University Press. http://dx.doi.org/10.1017/CBO9780511757754.011

Zare, J. (2012). Presupposition Trigger-A Comparative Analysis of Broadcast News Discourse. International Journal of Linguistics. http://dx.doi.org/10.5296/ijl.v4i3.2002

\section{Copyrights}

Copyright for this article is retained by the author(s), with first publication rights granted to the journal.

This is an open-access article distributed under the terms and conditions of the Creative Commons Attribution license (http://creativecommons.org/licenses/by/4.0/). 